\title{
日本循咭器学会専門医試験について
}

\section{日本循環器学会 認定試験委員会委員長窝崎俊}

第26回 (2015年度) の日本循環器学会専門医試 験は, 2015年 8 月 23 日に東京, 大阪の 2 会場で行 われた。受験申請者数は580名で，昨年より99名 増加している（これまでの経年変化は別表を参 照).

試験問題は日本循環器学会専門医研修カリキュ ラムに基づいて作成されており，その内容は，本 誌に掲載されているので参考として頂きたい。 ま た，一部の試験問題は公開することにしており，
その分野を専門とする先生方に解説頂いた.

2017年からは日本専門医機構による新しい専門 医制度がスタートする予定であり, 循環器専門医 制度も改変されることになるが，専門医試験の内 容そのものが変化するわけではない。受験生の先 生方はこれまで通りカリキュラムに沿つた学習を 日々の診療を通じて継続していくことが大事であ る.

\section{日本循環器学会専門医試験認定状況}

第 1 回 第 2 回 第 3 回 第 4 回 第 5 回 第 6 回 第 7 回 第 8 回 第 9 回 第10回 第11回 第12回 第13回

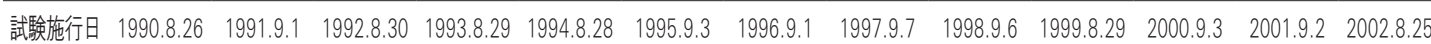
申請者数 77名 102名 196名 252名 336名 356名 447名 408名 483名 431名 528名 442名 467名 受験者数 77名 101名 193名 249名 365名 349名 443名 402名 477名 427名 525名 441名 464名 合格者数 70名 92名 174名 224名 330名 306名 397名 363名 431名 386名 452名 384名 400名 合格率 $90.9 \% \quad 91.1 \% \quad 90.2 \% \quad 90.0 \% \quad 90.4 \% \quad 87.7 \% \quad 89.6 \% \quad 90.3 \% \quad 90.4 \% \quad 90.4 \% \quad 86.1 \% \quad 87.1 \% \quad 86.2 \%$

第14回 第15回 第16回 第17回 第18回 第19回 第20回 第21回 第22回 第23回 第24回 第25回

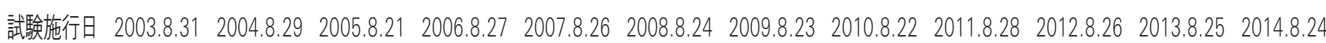
申請者数 569名 620名 704名 692名 735名 707名 688名 503名 491名 511名 433名 481名 受験者数 560名 612名 692名 680名 727名 699名 685名 502名 481名 508名 429名 479名 合格者数 494名 528名 605名 573名 640名 602名 598名 421名 411名 444名 384名 415名 合格率 $\quad 88.2 \% \quad 86.3 \% \quad 87.4 \% \quad 84.3 \% \quad 88.0 \% \quad 86.1 \% \quad 87.3 \% \quad 83.8 \% \quad 85.4 \% \quad 87.4 \% \quad 89.5 \% \quad 86.6 \%$ 


\section{日本循環器学会専門医試験問題}

問 1 重症大動脈弁狭窄について正しいのはどれか.

a．若年者ほど二尖弁が原因となる場合が多い.

b．50歳以上の患者には積極的に生体弁を用いる.

c. 80歳以上の高齢者は経カテーテル的大動脈弁置換術が第一選択となる.

d. 上行大動脈の高度石灰化を伴う症例に対しては大動脈基部置換術を選択する.

e. 左室駆出率が50\%以下の場合，心不全症状がない限り手術適応とはならない.

問 2 虚血性心疾患における心臓 MRI 検査で誤りはどれか.

a．遅延造影陽性領域は病理学的梗塞領域とよく一致する.

b. 石灰化のある冠動脈病変においても狭窄診断に影響がない.

c . 心筋梗塞において T2 強調像での高信号は心筋浮腫を反映する.

d，遅延造影 MRI により急性心筋梗塞と陳旧性梗塞の鑑別が容易である.

e．遅延造影 MRI による心内膜下梗塞巣の検出感度は心筋 SPECT 検査より高い.

問 3 慢性心不全の治療について正しいのはどれか.

a．拡張不全例では， $\beta$ 遮断薬が第一選択である.

b. アルドステロン拮抗薬は, 高カリウム血症を来さない.

c．心房細動を合併している場合は，Verapamil が第一選択である.

d．心臓再同期療法は，左脚ブロック型の QRS 幅の拡大した症例に適用する.

e. アンジオテンシン変換酵素阻害薬は副作用が多いため, アンジオテンシン II 受容体拮抗薬 を優先する. 
問 4 37歳女性. 呼吸困難と下肢浮腫を主訴に来院. 両側感音性難聴と筋力低下あり。血清乳酸值は $4.70 \mathrm{mmol} / \mathrm{L}$ (基準值0.44 1.33 mmol/L) で $\alpha$-galactosidase A 酵素活性は正常範囲内. 本人と 母親, 妹に遺伝子異常が発見された。心エコー傍胸骨長軸断層像を示す（図 1)。診断はどれか.
a. 肥大型心筋症
b 。 心ファブリー病
c . 心アミロイドーシス
d．ミトコンドリア脳筋症
e. デュシェンヌ型筋ジストロフィー

図 1

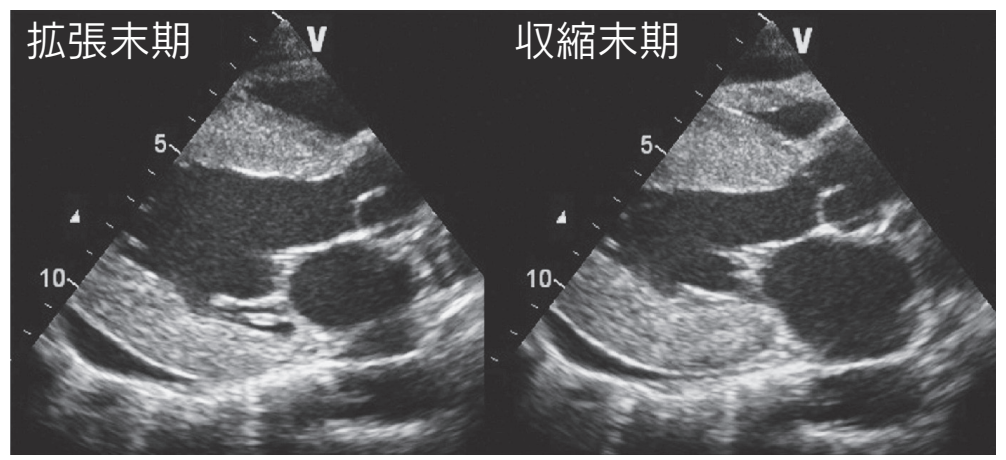

問 5 66歳の女性. 胸痛を訴え救急受診. 収縮期血圧 $64 \mathrm{mmHg}$, 脈拍数 $142 /$ 分, 呼吸数 38 /分, 初回 心エコー中に心停止に陥つた。 心エコー図を示す (図 2)。適切な治療方法はどれか. 2 つ選べ.
a. 血管拡張薬
b. 血栓溶解薬
c. dobutamine
d. 硫酸アトロピン
e. 経皮的心肺補助装置

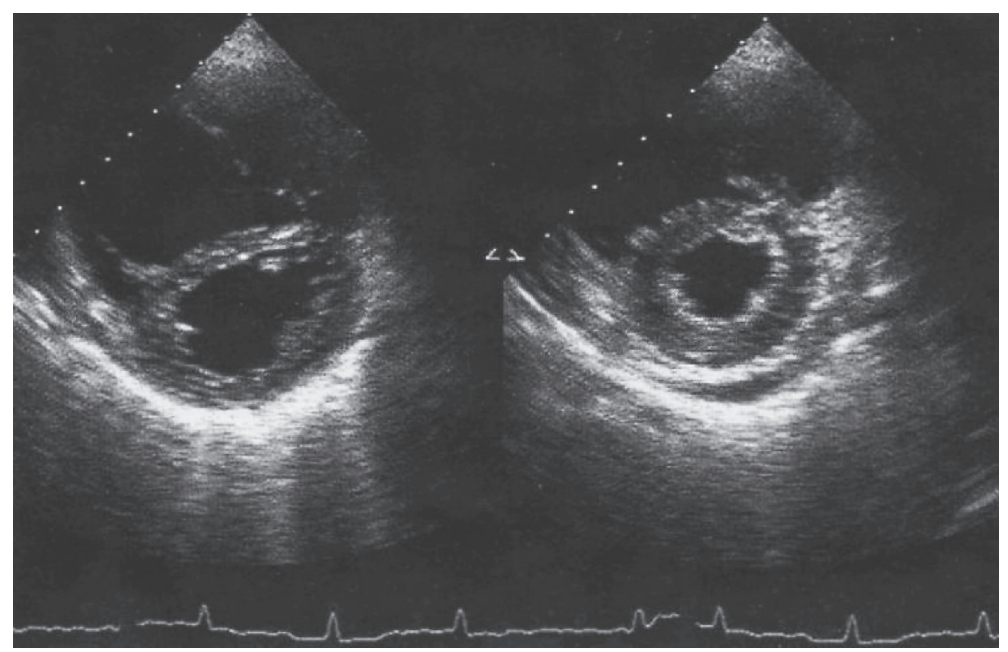


問 6 43歳の男性. 昨夜, 突然の失神発作を認めて救急入院となつた. 受診時の 12 誘導心電図を示す

（図 3)。入院後繰り返し心室細動発作が生じた。急性期の治療薬として適切なのはどれか.
a. Digoxin
b. Pilsicainide
c. Propranolol
d. Procainamide
e. Isoproterenol

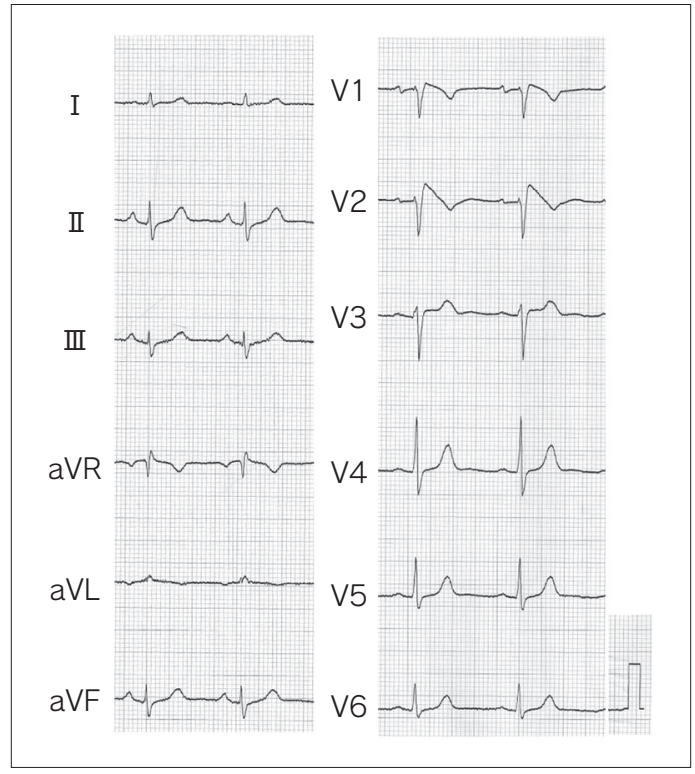




\section{日本循環器学会専門医試験問題 解答と解説}

\section{問 1 正解 a}

手術適応となるような重症大動脈弁狭窄の知識 を問う基本的問題である. メイヨークリニックで の外科切除標本による大動脈弁狭窄に対する年齢 別の原因検索では，70歳以上では退行変性（老人 性） $48 \%$ ，二尖弁 $27 \%$ ，炎症性 $23 \%$ に対して，70 歳未満では二尖弁50\%, 炎症性 $25 \%$, 退行変性 $18 \%$ と比較的若い年齢層で二尖弁の占める割合 が高かったと報告されている1)。a は正しい。生 体弁は抗凝固療法が不要となることが多いという 利点がある反面，機械弁に比して耐久性に問題が あり，一般的に高齢者に適用される. 日本循環器 学会の弁膜疾患の非薬物治療ガイドライン $(2012$ 年改訂版）によると生体弁による弁置換術に関す る推奨年齢は65歳以上とされている2)。 b は誤り. 経カテーテル的大動脈弁置換術 (TAVR or TAVI) は, 重症大動脈弁狭窄に対する新しい治療として 2000年代初頭より欧州で始まり, 全世界に広まっ たものである．本治療は大動脈弁置換術に比して 低侵襲ではあるが，歴史も浅くいまだ発展途上 の手技であり，現在のところ，通常の手術治療が 困難なハイリスク症例が対象とされている。目安 としては, STS score 8 以上あるいは Euroscore $15 \%$ 以上の症例とされている ${ }^{3)}$. 高齢者が本治療 の対象となることも多いが，年齢のみで適応が決 定されるわけではない。c は誤り。上行大動脈の 高度石灰化などをはじめとした動脈硬化性病変 は，大動脈弁置換術中にシャワー塞栓や大動脈解 離を起こすリスク因子である。高度大動脈石灰化
を伴う症例では脳合併症を予防するため, 送血部 位を腋窩動脈などに変更したり ${ }^{4)}$, 低体温循環停 止下に上行大動脈を切開し, 内腔を検索してから 遮断したり，さらに上行大動脈を人工血管置換し てから遮断したりする方法が試みられている5). 大動脈基部置換術は大動脈の拡張病変を伴う症例 に行われることがあるが，高度石灰化症例ではそ の適応とはならない。 $\mathrm{d}$ は誤り。日本循環器学会 の弁膜疾患の非薬物治療ガイドライン (2012年 改訂版 $)^{2)}$ によると, 重症大動脈弁狭窄で左室駆 出率が50\%以下の場合は, 自覚症状がなくても Class I で大動脈弁置換術の適応である. e は誤り.

\section{-文 献}

1) Passic CS, Ackermann DM, Pluth JR et al: Temporal changes in the cause of aortic stenosis: a surgical pathologic study of 646 cases. Mayo Clin Proc 1987; 62: $119-123$

2) 日本循環器学会学術委員会ガイドライン: 弁膜疾患の 非薬物治療ガイドライン (2012年改訂版) (大北裕 班長)

3) Smith CR, Leon MB, Mach MJ et al: Transcatheter versus surgical aortic valve replacement in high-risk patients. N Engl J Med 2011; 364: 2187-2198

4) Sabik JF, Lytle BW, McCarthy PM et al: Axillary artery: an alternative site of arterial cannulation fro patients with extensive aortic and peripheral vascular disease. J Thorac Cardiovasc Surg 1995; 109: 885-891

5) Coselli JS, Crawford ES: Aortic valve replacement in the patient with extensive calcification of the ascending aorta. J Thorac Cardiovasc Surg 1986; 91: 184187

[解説 鳥取大学心臓血管外科 西村元延]

\section{問 2 正解 d}

a 。遅延造影陽性領域は病理学的梗塞領域とよく 一致する.

ガドリニウム造影剤は血中から細胞外液に分布 するが，正常心筋では細胞外液腔は狭く，血流も 保持されているので 2 亿 分で平衡状態に達す
る.しかし，心筋梗塞では心筋細胞の破壊や線維 化，細胞膜障害のため，細胞外液腔が拡大する。 造影剤は緩徐に流入し流出が遅延するため，造影 10後に撮像すると心筋梗塞部が高信号の領域と して描出される。この結果, 遅延造影 MRI は, 病理学的梗塞領域をよく反映する ${ }^{1)}$. 
b. 石灰化のある冠動脈病変においても狭窄病変 に影響がない.

冠動脈狭窄診断能は1.5 T の whole heart coronary MRAに比較し64列 MDCTが優れている が, 冠動脈の石灰化が強い症例では MDCT によ る病変の評価は困難である。一方, $1.5 \mathrm{~T}$ の冠動 脈 MRA は，CT では診断困難な高度石灰化症例 における診断や造影剤が使用できない腎不全症例 における評価，川崎病の冠動脈瘤の診断などが可 能である ${ }^{2)}$.

c . 心筋梗塞において T2 強調像での高信号は心 筋浮腫を反映する.

T2 強調画像を用いることにより, 血流信号を 抑制し心臓の構造が評価できることから，急性心 筋梗塞における浮腫を高信号の領域として捉える ことができる゙).

d. 遅延造影 MRI により急性心筋梗塞と陳旧性 梗塞の鑑別が容易である.

慢性期の心筋梗塞領域は，遅延造影 MRI では 高信号を示すが, T2 強調画像では高信号を示さ
ない.このことから, 急性心筋梗塞と陳旧性心筋 梗塞を鑑別するためには, T2 強調画像と遅延造 影 MRI の組み合わが必要である ${ }^{4)}$.

e. 遅延造影 MRI による心内膜下梗塞巣の検出 感度は心筋 SPECT 検査より高い.

遅延造影 MRI による心内膜下梗塞の診断感度 は高 $<90 \%$ 前後であるのに対して, 心筋 SPECT での診断感度は20〜30\%と低值である ${ }^{5)}$.

\section{・文 献}

1) Kim RJ et al: Circulation 1999; 100: 1992-2002

2) Liu X, et al: AJR Am J Roentgenol 2007, 189: 13261332

3) Abdel-Aty H Zagrosek A et al: Circulation 2004; 109: 2411-2416

4) Abdel-Aty H Zagrosek A et al: Circulation 2004; 109: 2411-2416

5) Wagner A et al: Lancet 2003; 361: 374-379

[解説 東邦大学医療センター大森病院循環器内科

山㟝純一]

\section{問 3 正解 $\mathrm{d}$}

慢性心不全の治療を問う設問である。慢性心不 全の治療は収縮機能の低下した心不全（収縮不 全) についてはアンジオテンシン変換酵素 $(\mathrm{ACE})$ 阻害薬・アンジオテンシン II 受容体拮抗薬 (ARB) などのレニン・アンジオテンシン (RAS) 系阻害 薬, $\beta$ 遮断薬, アルドステロン受容体拮抗薬など が有効であることがすでに確立している，RAS 系阻害薬としては ACE 阻害薬が第一選択である. 咳などの副作用のために忍容性がそしい場合にの み $\mathrm{ARB}$ が適応となる。その理由は $\mathrm{ACE}$ 阻害薬 は長い歴史にわたつて心不全に有効であるとの工 ビデンスが豊富であるからである。 $\beta$ 遮断薬につ いてはコハク酸メトプロロール, カルベジロール, ビソプロロールの有効性が多くの大規模臨床試験 によって確立されている。わが国では，このうち カルベジロールとビソプロロールの保険適用が承 認されている.アルドステロン拮抗薬もスピロノ
ラクトンの有効性が認められており, NYHA III 度・IV度の心不全例への適応が承認されている. 本治療薬の問題点のひとつは女性化乳房である. 海外ではこの副作用のないエプレレノンも心不全 に使用可能であるが，わが国では心不全に対する 保険適用はない。アルドステロン拮抗薬は腎機能 低下例に使用するときに高力リウム血症に十分気 をつけることが必要である1).

a. 拡張不全例では, $\beta$ 遮断薬が第一選択である. $\beta$ 遮断薬は収縮不全には有効であることは確 立されているが，拡張不全に対するエビデン スはそしい2．メ

b. アルドステロン拮抗薬は, 高カリウム血症を きたさない.

上述のごとく，アルドステロン拮抗薬は高力

リウム血症をきたしやすい。 メ

c . 心房細動を合併している場合は, ベラパミル が第一選択である。 
心機能が正常な心房細動例の心拍数コント ロールにベラパミルが有効なのは周知の事実 であるが，心不全例に対しては心機能抑制効 果があるため要注意である。 メ

d。 心臓再同期療法は, 左脚ブロック型の QRS 幅の拡大した症例に適用する.

心臓再同期治療は QRS 幅の延長した症例, そのなかでも左脚ブロック型が良い適応とな る

e. ACE 阻害薬は副作用が多いため, ARB を優 先する.

上述のごとく, ACE 阻害薬が第一選択であ る. $\times$

\section{-文 献}

1) Juurlink DN, Mamdani MM, Lee DS et al: Rates of hyperkalemia after publication of the Radomized Aldactone Evaluation Study. N Engl J Med 2004; 351: 543-551

2) Hernandez AF, Hammill BG, O' Connor $\mathrm{CM}$ et al: Clinical effectiveness of beta-blockers in heart failure: findings from the OPTIMIZE-HF (Organized Program to Initiate Lifesaving Treatment in Hospitalized Patients with Heart Failure) Registry. J Am Coll Cardiol 2009; 53: 184-192

3) Vardas PE, Auricchio A, Blanc JJ et al European Society of Cardiology; European Heart Rhythm Association: Guidelines for cardiac pacing and cardiac resynchronization therapy: The Task Force for Cardiac Pacing and Cardiac Resynchronization Therapy of the European Society of Cardiology. Developed in collaboration with the European Heart Rhythm Association. Europace 2007; 9: 959-998

[解説 榊原記念病院循環器内科 吉川 勉]

\section{問 4 正解 d}

心肥大をきたす二次性心筋症の鑑別診断に関す る設問である.

ミトコンドリア脳筋症は, 心筋細胞内に存在す るミトコンドリアの機能異常によって心筋症や心 伝導障害を呈するミトコンドリア病のひとつであ る ${ }^{1)}$. 心筋細胞内において, ミトコンドリアは産 生される ATP (アデノシン三リン酸)を介してエ ネルギー産生に大きな役割を果たしており, 細胞 内の容積に占める割合も大きい。ミトコンドリア DNA の異常（変異や欠失）により生じるミトコ ンドリア病には MELAS (mitochondrial myopathy, encephalopathy, lactic acidosis and strokelike episodes), MERRF (myoclonus epilepsy associated with ragged-red fibers), 慢性進行性外 眼筋麻瘏症候群 (外眼筋麻痺, 網膜色素変性症, 心伝導障害: CPEO), その亜型の Kerns-Sayre 症 候群などが報告されている.

ミトコンドリアは全身のエネルギー産生も担つ ていることから, 心病変のみならず全身症状を 伴うことも多い. 感音性難聴, 小脳失調, 知能低 下などの中枢神経症状や, 網膜色素変性, 糖尿
病, 筋力低下, 白内障など多彩な症状を呈する. MELAS の場合, 病攣や意識障害などの脳卒中様 症状をきたす。臓の表現型としては肥大型が多 く, 著明な心肥大は左室の拡張機能低下を伴う. 一方で拡張型や拘束型も取りうること, 肥大型か ら拡張型に移行する拡張相肥大型心筋症様の病態 を呈することもある、また, WPW 症候群を含む 心室内伝導障害を合併するとの報告もある. 血液 検査では血中乳酸濃度が上昇する. 組織学的には 心筋細胞の空胞変性がみられ, 肥大型心筋症でも みられる錯綜配列などが観察される。心筋の電子 顕微鏡像でのミトコンドリアの形態異常（大小不 同，巨大化など）が診断の一助となる. 遺伝形式 は母系遺伝であるが, 必ずしも同じ臨床症状を呈 するとは限らないことに留意すべきである，確立 された根本的な治療法はなく, 中枢神経障害, 心 不全, 突然死が主な死因である ${ }^{1,2)}$.

本設問は心不全症状をともなつた若年女性で, 心エコー所見では対称性の著明な心肥大があり, 軽度の心囊液貯留を認めている. 上記のことを踏 まえると，ミトコンドリア脳筋症が正答である. 本例では, MELAS において報告のあるミトコン 
ドリア DNA の A3243G 点変異が認められた.

肥大型心筋症は, 非対称性中隔肥大がみられ, 心ファブリー病, 心アミロイドーシス, ミトコン ドリア脳筋症はいずれもその鑑別疾患としてあげ られる . 心ファブリー病は肥大型心筋症類似の 心エコー所見を呈することが多いが， $\alpha$-galactosidase A 酵素活性の低下が特徵的である. 近年, 酵素補充療法が行われ早期の治療開始により病状 進行を抑制する可能性が示唆されている ${ }^{1,3)}$. 心ア ミロイドーシスは心筋内へのアミロイド沈着をき たす疾患で, 通常対称性の心肥大を呈し, 心電図 上の四肢低電位や心室内伝導障害の所見が特徵的 で, 診断には心筋生検における Congo Redなど の染色による陽性所見が決め手となる，心藏での 診断が困難であれば消化管など他臓器での生検 が一助となるが，一般的に診断後の予後は不良で ある1,3). デュシェンヌ (Duchenne) 型筋ジストロ フィーは骨格筋の異常をきたして進行性の筋力低
下と筋萎縮がみられる疾患で, その多くが若年で 呼吸不全または心不全で死亡する。心臓では進行 性の心筋病変をきたして拡張型心筋症様の表現型 とともに心不全を合併することが多い1).

\section{・文 献}

1) 日本循環器学会など：昖張型心筋症ならびに関連する 二次性心筋症の診療に関するガイドライン (2011年版)

2) Sproule DM, Kaufmann P: Mitochondrial Encephalopathy, lactic acidosiss, and stroke episodes. Basic concepts, clinical phenolype, and therapeutic management of MELAS Syndrome. Ann NY Acad Sci 2008; 1142: 133-158

3) 日本循環器学会など : 肥大型心筋症の診療に関するガ イドライン（2012年改訂版）

[解説 山口大学医学部附属病院第二内科 奥田真一, 山口大学医学部大学院医学研究科器官病態内科学

矢野雅文]

\section{問 5 正解 $\mathrm{b}, \mathrm{e}$}

胸痛を主訴に救急受診した患者の救急診療に関 する質問である.

ER 収容時すでにショック状態で, 初療中に心 停止に陥つた66歳の女性の救命救急処置の質問で ある. ショックの救急診療は，まず呼吸管理を開 始しながらショックの 3 病態を考える. ショック の3 病態とは (1)volume (容量) が問題のショッ クか? (2)pump (ポンプ) が問題のショックか? (3)rate (心拍数) が問題のショックか? である. (1)volume (容量) が問題のショックと判断したな らば, 下肢を挙上し急速大量輸液（細胞外液 1〜 $2 \mathrm{~L}) を$, (2)pump (ポンプ) が問題のショックと 判断したならば, カテコラミン（収縮期血圧ミ $70 \mathrm{mmHg}$ ではノルアドレナリンを, 収縮期血圧 70〜90 mmHg ではドパミン) を, (3)rate（心拍 数）が問題のショックと判断したならば，不整脈 治療（頻拍性では電気的除細動を, 徐拍性ではア トロピンとペーシング）を開始する ${ }^{1,2)}$.

本症例は収縮期血圧が $64 \mathrm{mmHg}$, 脈拍数が
142/回, 呼吸数が38/回, 心エコー所見は右心室 の拡大と心室中隔の扁平化を認める. 急性右心過 負荷によるショック（右心室に過負荷がかかり機 能低下 $\rightarrow$ 肺循環系への右心拍出量が減少 $\rightarrow$ 左心室 内の血液充満量が減少 $\rightarrow$ 左心拍出量が著減 $\rightarrow$ 血圧 低下) による volume (容量) が問題のショックか ら, 急激に心停止に陥つている. 代表的な急性右 心過負荷性ショックには, 急性肺血栓塞栓症・右 室梗塞併発急性 ST 上昇下壁梗塞・急性心夕ンポ ナーデ (多くは, 急性 A 型大動脈解離に併発) が ある ${ }^{1,2)}$. この早期診断には, 右室梗塞併発急性 ST 上昇下壁梗塞では標準 12 誘導心電図十右側胸部 誘導 $\left(\mathrm{V}_{4} \mathrm{R}\right)$ が, 急性肺血栓塞栓症と急性心夕ン ポナーデでは心エコー・D ダイマーが有益であ る. 本症例は心エコー所見から急性心タンポナー デは否定的, 心エコー時の第 II誘導心電図モニ ター波形から右室梗塞併発急性 $\mathrm{ST}$ 上昇下壁梗塞 （右室枝を巻き込んだ右冠動脈近位部の閉塞）は 否定的である.すなわち, 急性肺血栓塞栓症によ る急性右心過負荷性ショックから心停止に至った 
可能性が高い. この救命救急処置は, 強力な循環 補助装置である経皮的心肺補助装置（percutaneous cardiopulmonary support: PCPS) を用いた 呼吸・循環管理（冠循環・脳循環および諸臓器の 循環を保持）しながら，原因疾患の急性期治療で ある ${ }^{1 \sim 3)}$. ヘパリンは PCPS 開始時から使用する. 本症例は収容時の血液検査で D ダイマー值の高 值が判明・心エコーに引き続いて行った下肢血管 エコーで深部静脈に欠損部を確認，PCPS下の肺 動脈造影（PCPS 駆動を一時停止）で肺動脈の閉 塞像を認め血栓溶解薬を投与した。 そして, 28
日後 独歩退院し社会復帰した。

・文 献

1) 循環器病の診断と治療に関するガイドライン，循環器 医のための心肺蘇生・心血管救急に関するガイドライ ン. Circ J, 73 (Suppl 3) : 2009

2) 日本救急医学会専門医認定委員会 (編): 救急診療指針, 第 4 版，へるす出版，東京， 2011

3）循環器病の診断と治療に関するガイドライン. 肺血检 塞栓症および深部静脈血栓の診断・治療・予防に関す るガイドライン (2009年改訂版)。Circ J, 75(5)

[解説 日本大学循環器内科長尾建]

\section{問 6 正解 e}

Brugada 症候群の治療に関する問題である. Brugada 症候群は突然死の原因疾患として注目 されており, 明かな器質的心疾患を認めず, 心電 図上 $V_{1} \sim V_{3}$ 誘導において特徵的な ST 上昇を示 し, 心室細動を発症しやすい疾患として知られて いる. Brugada 症候群は男性に多く, 東南アジ ア地区に発症頻度が高く, 好発年齢は30～50歳 とされており, 本疾患の心電図所見を認める頻度 は成人で $0.05 \sim 0.6 \%$ と報告されている. 診断上, 重要な心電図所見は $V_{1} \sim V_{3}$ 誘導の coved 型およ び saddleback 型 ST 上昇であり, Type1,2,3 に分 類されている. 薬物負荷および上位胁間の記録を 含め, 右側胸部誘導にて 1 つ以上 Type1 (coved 型， $\mathrm{J} \geqq 0.2 \mathrm{mV}$ ) の心電図を示した場合, (1)多形 性心室頻拍・心室細動が記録されている (2)45歳 以下の突然死の家族歴がある (3)家族に典型的 Type 1 の心電図を認める者がいる (4)多形性心室 頻拍・心室細動が心臓電気生理学的検查によって 誘発される (5)失神や夜間の瀕死期呼吸を認め る,のうち 1 つ以上を満たすと本疾患として診断 される.

図 3 の心電図では $V_{1} \sim V_{2}$ 誘導において典型的 な coved 型 ST 上昇を示し, $V_{2}$ 誘導では Type 1 心電図を呈している.さらに，失神を契機で入院 し，心室細動を繰り返して認めている。つまり, 急性期の心室細動（electrical storm）にいたつた
Brugada 症候群であり, 治療の選択肢としてイ ソプロテレノール (ISP) が正解である. ピルシ カインド, プロプラノメールおよびプロカインア ミドはむしろ Brugada 症候群の病態を悪化させる.

欧米のガイドラインでは ISP を $0.01 \mu \mathrm{g} / \mathrm{kg} / \mathrm{min}$ から開始し, 心電図変化を確認しながら投与量を 調節することが推奨されている. わが国の報告で は ISP 低用量 $1 \sim 2 \mu \mathrm{g}$ をボーラス投与し, その後 $0.15 \mu \mathrm{g} / \mathrm{min}$ 持続点滴，または0.003 0.006 $\mu \mathrm{g} /$ $\mathrm{kg} / \mathrm{min}$ 持続点滴が有効とされている ${ }^{1,2)}$. 作用機 序として, ISP による $\beta$ 受容体刺激作用により, $\mathrm{L}$ 型 $\mathrm{Ca}$ チャネルによる内向き電流 ( $\mathrm{ICaL}$ ) の増 加と心拍数上昇 ( $\mathrm{R}-\mathrm{R}$ 間隔短縮) による一過性 外向き $\mathrm{K}$ 電流 $\left(\mathrm{I}_{\mathrm{to}}\right)$ の減少と考えられている. 臨床的には ISP による心室細動抑制効果として $\mathrm{R}-\mathrm{R}$ 間隔短縮より $\mathrm{ST}$ 上昇の改善の寄与が大き いとされている1).

\section{・文 献}

1) Watanabe A et al: Low-dose isoproterenol for repetitive ventricular arrhythmia in patients with Brugada syndrome. Eur Heart J 2006; 27: 1579-1583

2) Ohgo $T$ et al: Acute and chronic management in patients with Brugada syndrome associated with electrical storm of ventricular fibrillation. Heart Rhythm 2007; 4: 695-697

[解説 国家公務員共済組合連合会横浜南共済病院循環器内科 西㟝光弘］ 